\title{
Growth Parameters and Yield of Green Gram Varieties (Vigna radiata L.) in East and South East Coastal Plain of Odisha, India
}

\author{
S.R. Dash* and B.K. Rautaray \\ Krishi Vigyan Kendra, Jagatsinghpur, OUAT, Bhubaneswar, Odisha, India \\ *Corresponding author
}

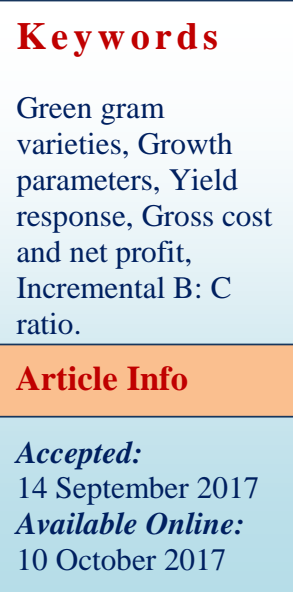

\section{Introduction}

Pulse, the food legume has been grown since millennium and has been a vital ingredient of the human diet in India. Pulse and milk provide the full complement of proteins to people who avoid eating meat. Pulse is the second most important groups after cereals. In year 2016 -17 the total pulse area 238.56 lakh ha with production in India was 18.25 million tonnes with productivity $765 \mathrm{~kg} \mathrm{ha}^{-1}$. India is the largest producer and consumer of pulse in the world, accounting for 25 percent of global production and 15 percent consumption
(Saraswati et al., 2004). Pulse is the most important food crop in India and from all integral part of the cropping system farmers all over the country. Pulse crops are primarily grown under rain fed condition and a low fertility neglected soil in India. It can be grown on a variety of soil and climatic conditions as it is tolerant to drought (Malik et al., 2006).Green gram or mung bean (Vigna radiata $\mathrm{L}$.) is the major pulse crop of the state Odisha covering total area of 8.36 lakh ha with average productivity $434 \mathrm{~kg}$ per ha, 
which is about 40 percent of the total pulse area of the state and in coastal belt green gram and black gram are the major pulse. The district of Jagatsinghpur lies in the agroclimatic zone of east and south east coastal plain zone of Odisha extending from $20-21^{0}$ North latitude to $84-87^{0}$ East longitude. The district consists of eight blocks ie Jagatsinghpur, Raghunathapur, Balikuda, Biridi, Naugaon, Tirtol, Kujanga and Erasama. The Average Normal Rainfall of this district is $1521.16 \mathrm{~mm}$ and more than $75 \%$ of the precipitation is received over five months i.e. June- October. The maximum and minimum temperature of this district is $38^{\circ} \mathrm{C}$ and $12^{\circ} \mathrm{C}$ respectively. Agriculture is the main occupation and backbone of the district economy. The rich fertile soils of Mahanadi, make the region good for cultivation of different crops. Paddy is the subsistence crop and grown in 81,540 thousand ha. Apart from paddy, green gram, black gram and vegetables are grown in the district.

Pulses like green gram (mung) and black gram grown all most all areas. Residual soil moisture is fully utilized by the farmers in the fields for cultivation of pulse crops. Including mung bean in the rice rotation system has diversified and strengthened the cropping system, alleviated the disadvantage of cereal cereal cropping system and improved the productivity of the soil.

Including the mung bean in a rice rotation has increases the yield of paddy and the income of the farmer (Weinberger, 2003) the green gram is the major pulse grown in the district Jagatsinghpur only in rabi season under residual moisture condition after harvest of Kharif paddy. Green gram is cultivated as major pulse crop in all the eight blocks of the district comprising total area of 38,120 ha with productivity of $430 \mathrm{~kg} \mathrm{ha}^{-1}$, which is very low as compared to national and state average.
The farmers are using local cultivators ie Jhain Mung which gives poor yield. Generally the farmers are not adopting any nutrient and biofertilizer application and YMV is the major reason for poor yield in this area. As the crop is grown in residual soil moisture, the crop faces water stress condition many times. One of the major constraints of poor yield and spread of green gram, is the non-availability of suitable high yielding variety to replace the traditional varieties.

\section{Materials and Methods}

The study was carried out in operational village Bagoi, of Krishi Vigyan Kendra (KVK), Jagatsinghpur during Rabi 2016-17. The study was under taken in Kujanga block of Jagatsinghpur district of Odisha and the block was selected purposefully as green gram is the major crop in Rabi season. The geographic location of the area was with Longitute-86-34'33.9" E, Latitude20-19'34.6" $\mathrm{N}$ and soil and nutrient status of the experimental site is given below. The climate of the region is hot and humid climate with average rainfall $1500 \mathrm{~mm}$. The treatments were consisted of four different high yielding varieties and one local green gram variety i.e., T1: TARM-1, T2: IPM-02-14, T3: Pusa Vishal, T4: SML-668, and T5: Local (check).and were replicated five times in randomized block design. Four different high yielding green gram varieties and one local variety (Jhain Mung) were grown with recommended package and practices. The field was ploughed two times and planking was done after each ploughing, then seeds were inoculated with Rhizobium culture @20.0 gm per kg seed, and sown in line by using seed cum fertilizer drill with spacing $20 \mathrm{x} 10 \mathrm{~cm}$. and seed rate was $20 \mathrm{~kg} / \mathrm{ha}$. Need based plant protection measures were taken against pod borer and YMV infestation. Soil application of PSB @ $5 \mathrm{~kg} / \mathrm{ha}$, along with soil test based fertiliser application was done with 
Fertilizer dose NPK - 20:40:20 kg ha ${ }^{-1}$ (N: P: $\mathrm{K})$ and all fertilizers were applied at basal. Spraying of Thiomethoxam @ 165gm/Ha for sucking pest management, spraying of Chloropyriphos and Cypermethrin $2 \mathrm{ml} / \mathrm{lit}$ for pod borer control and Foliar spray of Bio Vita and Humic acid $2 \mathrm{ml} / \mathrm{lit}$ at 30DAS was followed along with Installation of yellow sticky Trap@ 20 nos./ha for management of white fly and YMV. The seeds and other critical inputs were supplied to the farmers by KVK.The plot size was $(10 \mathrm{X} 10) \mathrm{m}$. The crops were sown during January second week and harvested during first week of April. Parameters like Plant height, number of pods plant $^{-1}$, pod length, number of seeds pod $^{-1}$, 100 seed weight, Stover yield and grain yield were recorded at maturity stage and the gross returns ( $\mathrm{Rs} \mathrm{ha}^{-1}$ ) were calculated on the basis of prevailing market price of the produce. The benefit cost ratio of different varieties was calculated by dividing the gross return by cost of cultivation. The data were statistically analyzed applying analysis of variance and significance of different sources of variations were tested by error means square of Fisher Snedecor's ' $F$ ' test at probability level of 0.05 (Cochran and Cox,1977).

\section{Results and Discussion}

The experimental findings obtained from the present study have been presented in the table- 2 and discussed in the following heads

\section{Plant height and no of branches per plant}

The data on crop growth parameters as reported in Table 2 indicated that the tallest plants were recorded in variety TARM-1 $(55.78 \mathrm{~cm})$ followed by High yielding variety Pusa Vishal and SML-668 having height of $(53.80 \mathrm{~cm})$ and $51.38 \mathrm{~cm}$ respectively. The rest of the variety had plant height at par with IPM-02-14. The variety Pusa Vishal produced maximum no of branches per plant (6.20) followed by TARM-1.The reason may be attributed to the genetic variability and varietal difference and environmental adoptability. Similar results were also reported by Samant (2014).

\section{Length of the pod and no of pods per plants}

The longest pod $(8.07 \mathrm{~cm})$ produced in variety Pusa Vishal which is significantly higher than TARM-1.The variety SML-668 and IPM 0214 were equivalent and the shortest pod was produced in Jhain Mung. The maximum no of pod per plants (18.36) was recorded in variety TARM-1 whereas minimum no of pods was found in SML-668(Table-1). The rest of the variety have moderate no pods per plants. The findings are in corroborated with the findings of Rathod and Gawande (2014).

\section{No of seed per pod and test weight}

Variety TARM-1 recorded maximum no of seed per pod (11.52) and minimum no of seeds per pod was obtained in SML-668 (10.20) which is significantly higher. The rest of the varieties were equivalent. The highest test weight (100 seed weight) was obtained in variety Pusa Vishal (4.93g) and minimum test weight recorded in local variety Jhain Mung (2.46g). The reason may be attributed towards the genetic variability and bold grain size in case of Pusa Vishal. Similar result about seed test weight was reported by Uddin et al., (2009) and Yadav et al., (2007).

\section{Plant dry weight and plant height}

Among the different green gram variety in the study variety Pusa Vishal achieved maximum dry weight per plant (14.62g) followed by variety IPM 02-14 (12.84g) which is significantly higher vas compare to other treatments. This might be attributed due to better establishment of crop plants, greater plant height and more number of branches per plant of Pusa Vishal. 
Table.1 Soil nutrient status of the trial plot

\begin{tabular}{|c|c|}
\hline Soil test report & Village - Bagoi(Trial plots) \\
\hline $\mathrm{pH}$ & 6.70 \\
\hline $\mathrm{EC}(\mathrm{dS} \mathrm{m}-1)$ & 0.68 \\
\hline Available $\mathrm{N}(\mathrm{Kg} \mathrm{ha}-1)$ & 347.00 \\
\hline Available P2O5 (Kg ha-1) & 45.00 \\
\hline Available K2O (Kg ha-1) & 364.00 \\
\hline Organic carbon (\%) & 0.73 \\
\hline
\end{tabular}

Table.2 Agronomical Parameters of green gram varieties observed in farmer's field during Rabi 2016-17

\begin{tabular}{|c|c|c|c|c|c|c|c|c|c|}
\hline Treatment & $\begin{array}{c}\text { Mean Plant } \\
\text { Height at } \\
\text { harvest } \\
(\mathrm{cm}) \\
\end{array}$ & $\begin{array}{c}\text { No } \\
\text { Branch } \\
\text { es plant } \\
-1\end{array}$ & $\begin{array}{l}\text { No of } \\
\text { pods } \\
\text { plant }^{-1}\end{array}$ & $\begin{array}{c}\text { Pod } \\
\text { length } \\
(\mathrm{cm})\end{array}$ & $\begin{array}{l}\text { No of } \\
\text { seeds } \\
/ \text { pod }^{-1}\end{array}$ & $\begin{array}{l}100 \text { seed } \\
\text { wt. }(\mathrm{gm})\end{array}$ & $\begin{array}{c}\text { Plant } \\
\text { dry } \\
\text { weight } \\
\text { (gm) } \\
\end{array}$ & $\begin{array}{c}\text { Seed } \\
\text { Yield } \\
\left(\mathbf{q} \text { ha }^{-1}\right)\end{array}$ & $\begin{array}{c}\text { Stover's } \\
\text { yield } \\
\left(\mathrm{q} \mathrm{ha} \mathbf{p}^{-1}\right)\end{array}$ \\
\hline T1: TARM-1 & 55.78 & 5.80 & 18.36 & 7.40 & 11.52 & 3.98 & 12.80 & 7.74 & 28.12 \\
\hline T2: IPM-02-14 & 46.48 & 4.40 & 13.20 & 6.99 & 10.34 & 3.65 & 12.84 & 8.12 & 30.04 \\
\hline T3: PusaVishal & 53.80 & 6.20 & 13.80 & 8.07 & 10.92 & 4.93 & 14.62 & 11.18 & 46.48 \\
\hline T4: SML-668 & 52.06 & 5.40 & 11.60 & 6.92 & 10.20 & 3.52 & 12.24 & 7.96 & 27.70 \\
\hline T5:Local (Check) & 51.38 & 5.60 & 19.00 & 6.52 & 10.42 & 2.46 & 11.66 & 6.62 & 22.24 \\
\hline S.E $(m) \pm$ & 2.36 & 0.45 & 1.45 & 0.22 & 0.30 & 0.17 & 0.30 & 0.31 & 0.46 \\
\hline C.D. $(\mathrm{P}=0.05)$ & $7.13 N S$ & $1.36 \mathrm{NS}$ & $4.38 N S$ & $0.68 *$ & $0.92 *$ & $0.51^{*}$ & $0.90 *$ & 0.94* & $1.40^{*}$ \\
\hline C.V.\% & 10.16 & 18.34 & 21.33 & 6.97 & 6.37 & 10.24 & 5.21 & 8.40 & 3.27 \\
\hline
\end{tabular}

NS-Not significant, *Significant at $P=0.05$ level of probability,

Table. 3 Cost of cultivation and economics

\begin{tabular}{|l|c|c|c|c|}
\hline Variety/treatments & $\begin{array}{c}\text { Cost of } \\
\text { Cultivation } \\
\left(\text { Rs ha }^{-\mathbf{1}}\right)\end{array}$ & $\begin{array}{c}\text { Gross Return } \\
\left(\text { Rs ha }^{\mathbf{- 1}}\right)\end{array}$ & $\begin{array}{c}\text { Net Return } \\
\left(\text { Rs ha }^{-\mathbf{1}}\right)\end{array}$ & $\begin{array}{c}\text { Benefit Cost } \\
\text { ratio } \\
\text { (B:C ratio) }\end{array}$ \\
\hline T1: TARM-1 & 18340 & 40248 & 21908 & 2.19 \\
\hline T2: IPM-02-14 & 18250 & 42224 & 23974 & 2.31 \\
\hline T3: Pusa Vishal & 20850 & 58136 & 37286 & 2.80 \\
\hline T4: SML-668 & 18400 & 41392 & 22992 & 2.24 \\
\hline T5: Local (check) & 16350 & 34424 & 18074 & 2.10 \\
\hline
\end{tabular}


Fig.1 Blockwise area of green gram in Jagatsinghpur district 2015-16

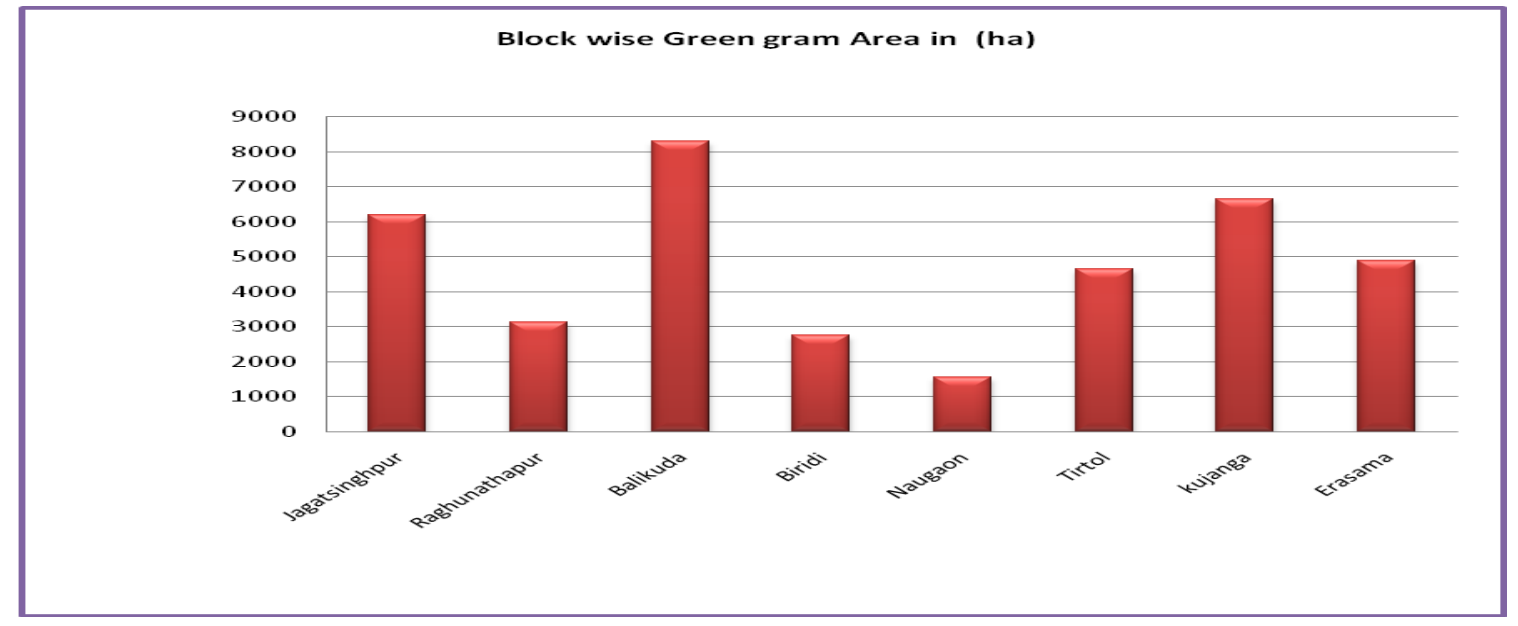

Fig.2 Effects of treatments on plant height and no of branches plant ${ }^{-1}$

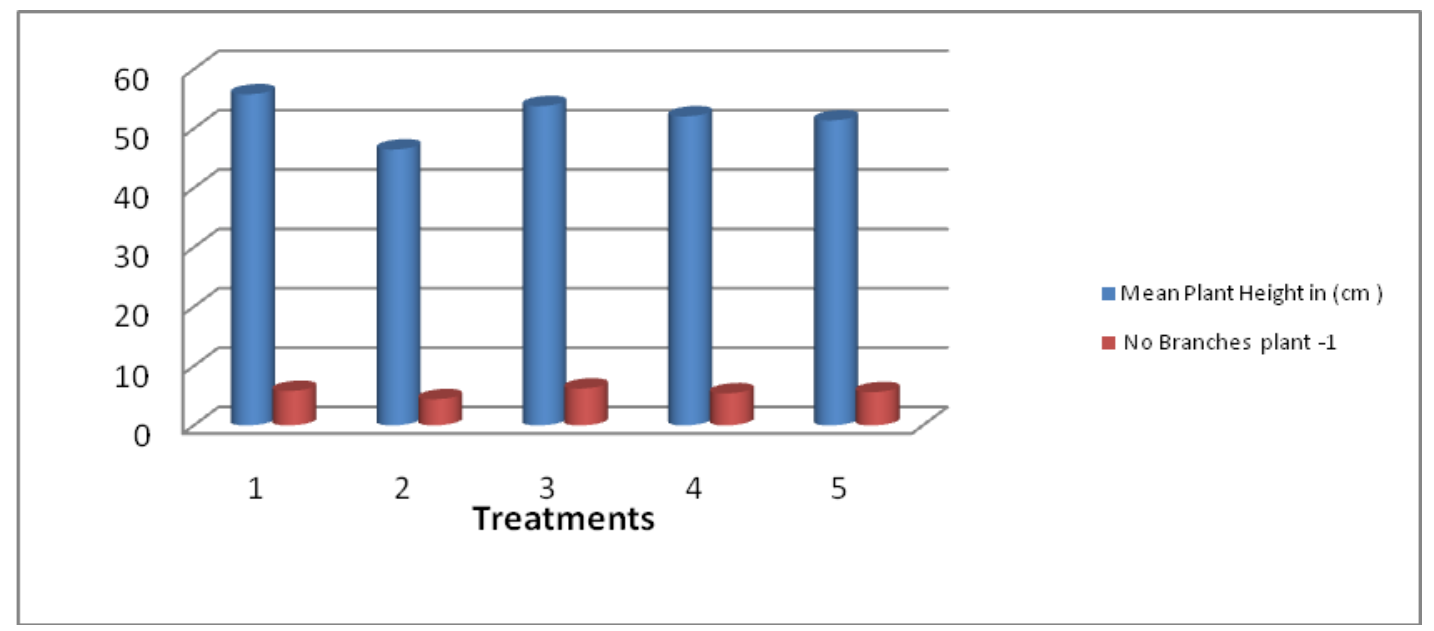

Fig.3 Cost of cultivation, gross return and net profit green gram varieties

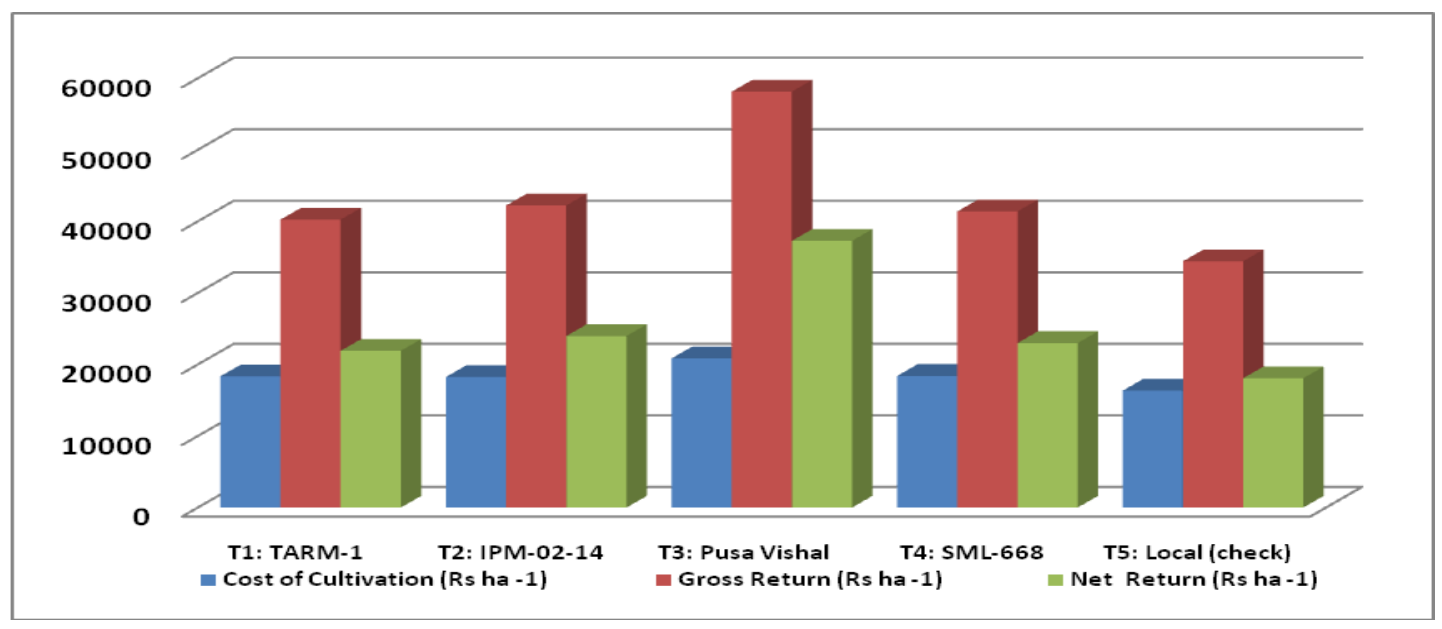




\section{Seed yield and Stover's yield}

The seed yield of different high yielding varieties of green gram recorded in Table-1 ranged from 6.62 to $11.18 \mathrm{q}$ per ha which was significantly higher yield than that with existing local variety Jhain Mung. The variety Pusa Vishal exhibited maximum seed yield $11.18 \mathrm{q} / \mathrm{h}$ a due to higher optimum no of pods per plants, longer pod size, more no of branches and bold seed size and higher test weight and good crop stand. The variety IPM -02-14 and SML-668 recorded an equivalent yield of $8.12 \mathrm{q} / \mathrm{ha}$ and $7.96 \mathrm{q} / \mathrm{ha}$ respectively. The grain yield of variety TARM-1 is $7.74 \mathrm{q} / \mathrm{ha}$ which is at par with SML -668 and IPM 02-14. The lowest seed yield was obtained from Jhain Mung (6.62q/ha). The trend of storver's yield of different was almost similar with seed yield. Maximum Stover's yields was obtained from variety Pusa Vishal 48.46 q/ha owing to high dry matter accumulation whereas the local Jhain Mung produced least stover's yield 22.24q/ha. These results are similar with the findings of Uddin et al., (2010).

\section{Economics and Benefits cost ratio}

The economics of different HYV green gram varieties have been presented in Table-3.The results of economic analysis of green gram production revealed that the gross expenditure in case of Pusa Vishal was higher than Farmer's variety (Local check).The HYV green gram Pusa Vishal recorded highest gross return and net profit of Rs.58136 ha ${ }^{1} \&$ Rs.37286 $\mathrm{ha}^{-1}$, respectively. The same variety had also maximum Incremental B: C ratio $(2.80)$ due to higher productivity which was followed by IPM-02-14, SML-668 and TARM-1. These findings are similar with findings of Patel et al., (2013) and Samant, T.K. (2014)

The results from the trial have conclusively proved that the yield of Pusa Vishal was significantly higher than other varieties with recommended agronomical package and practices. Thus the existing local variety may be replaced with high yielding variety Pusa Viushal and IPM 02-14. Because of higher productivity and net income Pusa Vishal and IPM-021-14 were found to be most suitable and promising varieties since these two varieties are performed well to the existing farming situation and also it had been appreciated by the farmers.

\section{References}

Cochran, W.G., Cox G M., 1977. Experimental Design, Asia publishing House, Kolkata, pp 95-132 and 142181.

Dixit, P.M., and Elamathi, S. 2007. Effect of foliar application of dap, micronutrients and NAA on growth and yield of green Gram (Vigna radiata L.) Legume res., 30 (4): $305-307$.

Lalit, M., Patil1, D. J. Modi2, H. M. Vasava3 S. R. Gomkale4 2014. Evaluation of Front Line Demonstration Programme on Green gram Variety Meha (IPM-99125) in Bharuch district of Gujarat Volume 8, Issue 9 Ver. I (Sep. 2015), PP 01-03.

Malik, A., Fayyaz-Ul- Hassan,,a. Abdul Wahieed A.,Qadir G., and Asghar, R. 2006. In reactive effects of irrigation and Phosphorus on green gram Vigna radiata L, pakisthan J Bot, 38(4):11191126.

Patel, H.R., Patel, F.H., Maheriya, V.D and Dodia, I.N 2013. Response of Kharif green gram (Vigna radiata L) to Sulphur and Phosphorus with and without biofertilizer application. Bioscan, 8(1):149-152.

Rajesh, M., Kaliyamoorthy Jayakumar *, T. M. Sathees Kannan 2013. Effect of Biofertilizers Application on Growth and Yield Parameters of Green Gram (Vigna radiata L.). International Journal 
of Environment and Bioenergy, 7(1): 43-53.

Rathod, S.L., and Gawande M. B. 2014 Response of greengram varieties to different fertilizers grades, International Journal Science and Research (IJSR) 3(7) $\mathrm{p}-1313-1315$.

Samant, T.K., 2014. Evaluation of Growth and Yield parameters of Greengram (Vigna radiata $\mathrm{L}$ ), Agriculture Update, 9(3) p-427-430.

Saraswati, R., Krishnamurthy, R., and Singaram, P. 2004. Nutrient management for rain fed green gram, Madras Agric, J, 91:230-33.

Singh, P.K., Singh S.K, Shukla, M, K., Singh C., Singh R., Singh SS, Prasad, P. 2016. Growth and yield of green gram (Vigina radita L.) as influenced by bio- fertilizer, tillage practices and weed control methods, 3(7), www.allsubjectjournal.com p. 254-256

Singh, R., Sharma, A. K., Singh, S.P. 2012. Agricultural Statistics, Test of significance. Aman Publishing House Meerut, UP, pp196-245.

Uddin, Md, S., A.K.M.R Amin, Md Mahammad Ullah and Mahammad Asaduzzman 2009. In traction effect of variety and different fertilizers on growth and yield of summer greengram. American -Eurasian Journal Agronomy, 2(3) p-180-184. IDOSI publications.

Weinberger, K., 2003. Impact analysis of mung bean research in South and Southeast Asia, Final Report of GTZ Project. The world vegetable center (AVRDC), Shanhua, Taiwan.

\section{How to cite this article:}

Dash, S.R. and Rautaray, B.K. 2017. Growth Parameters and Yield of Green Gram Varieties (Vigna radiata L.) in East and South East Coastal Plain of Odisha, India. Int.J.Curr.Microbiol.App.Sci. 6(10): 1517-1523. doi: https://doi.org/10.20546/ijcmas.2017.610.181 